\title{
A Step Back in Time- \\ A Brief Geological History of Cockspur Island at Fort Pulaski National Monument, Chatham County, Georgia
}

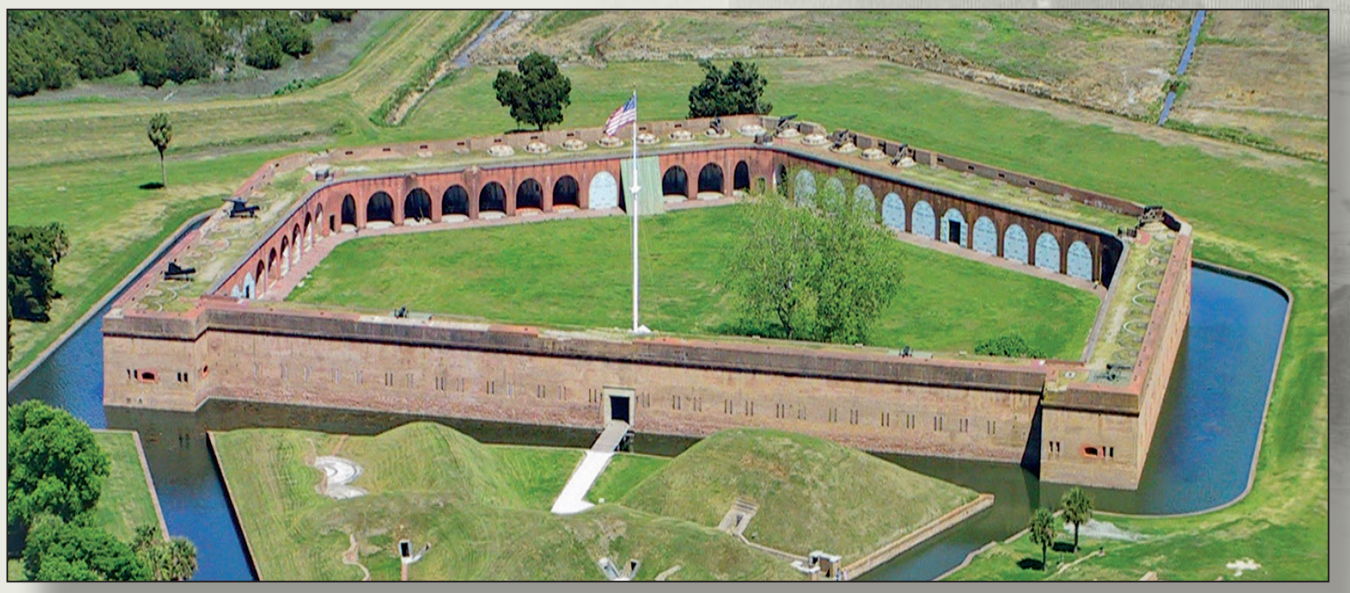

Figure 1. Photograph of Fort Pulaski National Monument, Chatham County, Georgia.

Fort Pulaski was constructed from 1829 to 1847 and was designated a national monument by proclamation of President Calvin Coolidge in 1924. The fort is located on Cockspur Island in Chatham County, Georgia, within the Atlantic Coastal Plain province of the southeastern United States (figs. 1 and 2). The island lies near the mouth of the Savannah River, and consists of small mounds (hummocks), salt marshes, and sediment dredged from the river.

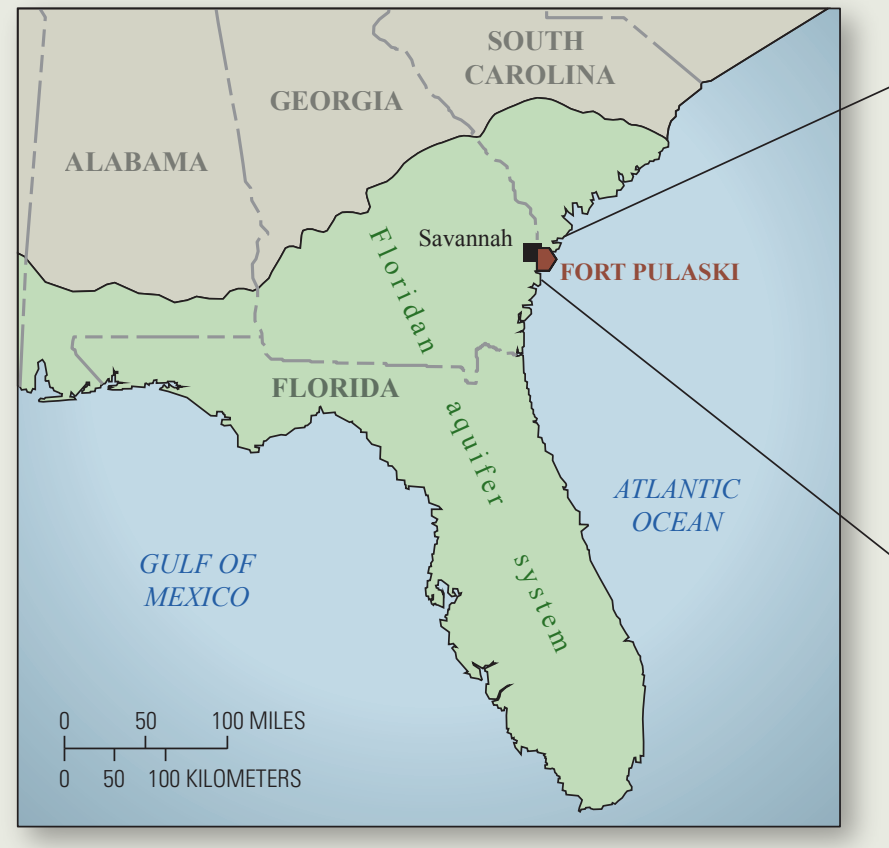

Figure 2A. Map showing the location of Fort Pulaski and the Floridan aquifer system (shaded in green) in the southeastern United States. Figure modified from Williams and Kuniansky (2016).

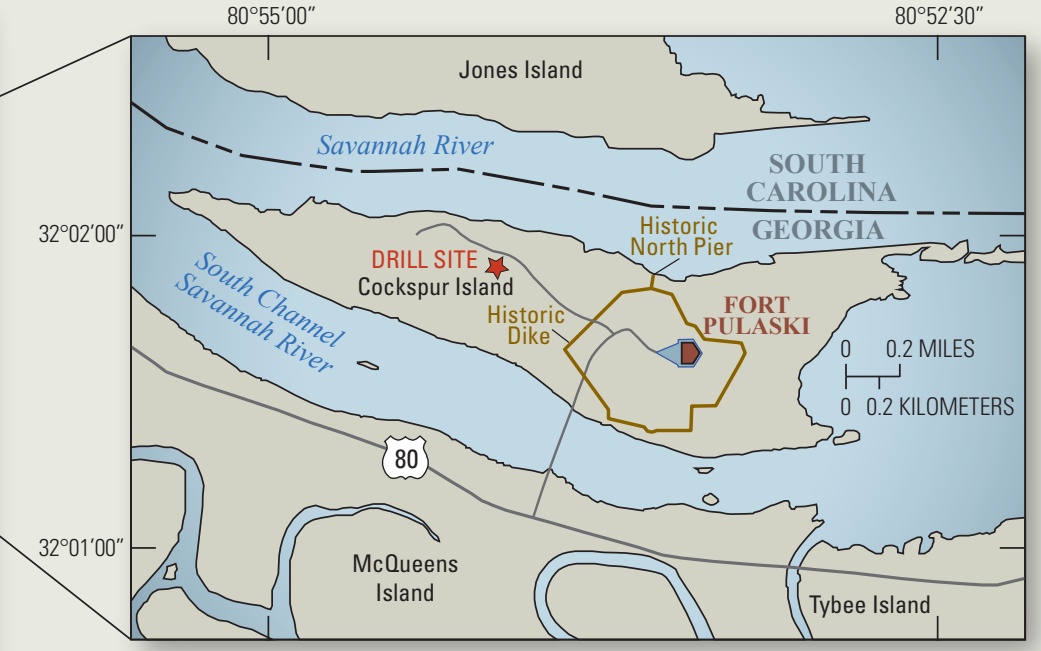

Figure 2B. Map of Fort Pulaski National Monument, Chatham County, Georgia. The red star marks the location of the drill site and the Cockspur Island core described in figure 3. North of Cockspur Island, the middle of the Savannah River forms the boundary between the States of Georgia and South Carolina. 


\section{Stratignaphy of Cockspun Osland}

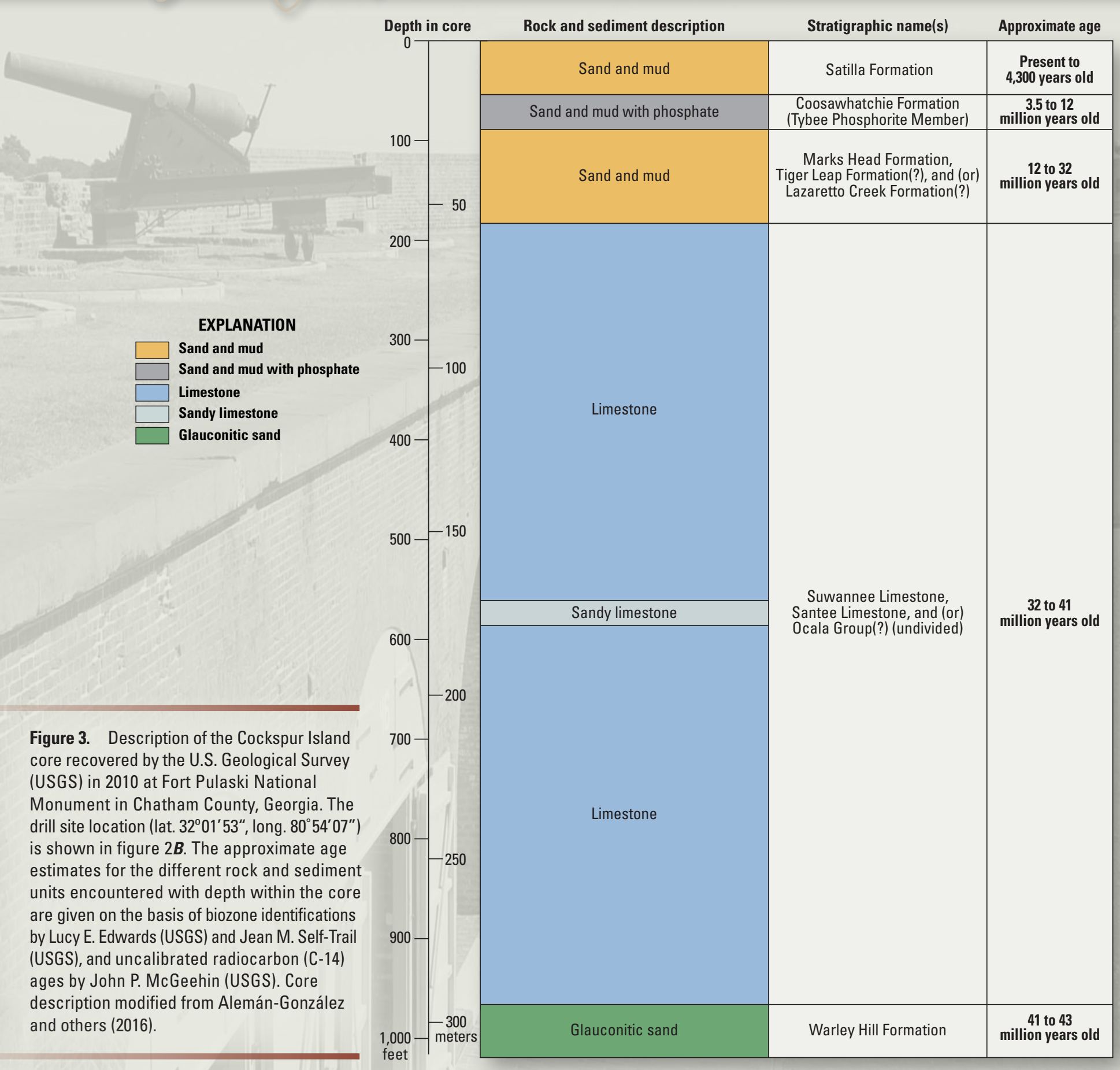

Several studies have been published on the geology of Cockspur Island. Weems and Edwards (2001) published a description of a 116.5-foot (ft) (35.5-meter [m]) core drilled on the north side of the island. In 2010, the U.S. Geological Survey drilled a 1,017-ft $(310-\mathrm{m})$ core to determine the stratigraphy of Cockspur Island west of Fort Pulaski (fig. 3). The core from top to bottom consists of the following five sedimentary units: (1) a 53-ft (16-m)-thick unit of sand and mud, ranging in age from present to 4,300 years old; (2) a 35-ft (11-m)-thick unit of sand and mud with phosphate, ranging in age from 3.5 to 12 million years old; (3) a 94-ft (29-m)-thick unit of sand and mud, ranging in age from 12 to 32 million years old; (4) a 783-ft (239-m)-thick unit of limestone, ranging in age from 32 to 41 million years old (includes $\sim 25 \mathrm{ft} \mathrm{[7.6} \mathrm{m]} \mathrm{of} \mathrm{sandy} \mathrm{limestone);} \mathrm{and} \mathrm{(5)} \mathrm{a} \mathrm{53-ft} \mathrm{(16-m)-thick} \mathrm{unit} \mathrm{of} \mathrm{glauconitic} \mathrm{sand,} \mathrm{ranging} \mathrm{in}$ age from 41 to 43 million years old. The limestone and water within the limestone are referred to collectively as the Floridan aquifer system (fig. $2 \boldsymbol{A}$ ), which is the primary source of drinking water for the City of Savannah and surrounding communities. In addition to discussing the subsurface geology, this fact sheet identifies a variety of geologic materials used in the construction of Fort Pulaski. These materials include granite, bricks, sandstone, and lime mud with oyster shells (figs. 4A-D). 


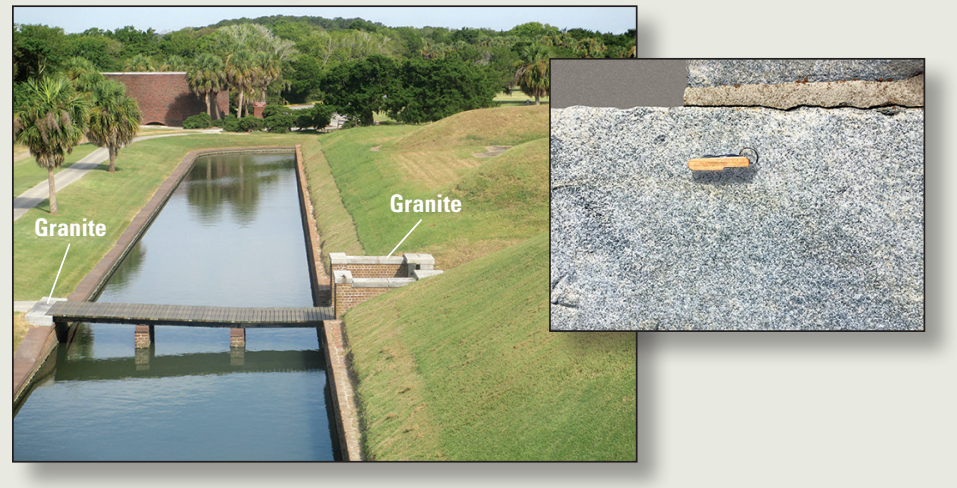

A. Granite - Blocks of granite were used as stairs, the tops of brick posts, walls, and as a lining along the old wharf at the Historic North Pier (fig. 2B). Granite is an igneous rock formed by the cooling and solidification of liquid magma. Most of the granite was quarried in New England, transported to New York, and then transported by ship to Fort Pulaski. At Fort Pulaski, four varieties of granite were used that may range in age from 280 million to 1 billion years old.

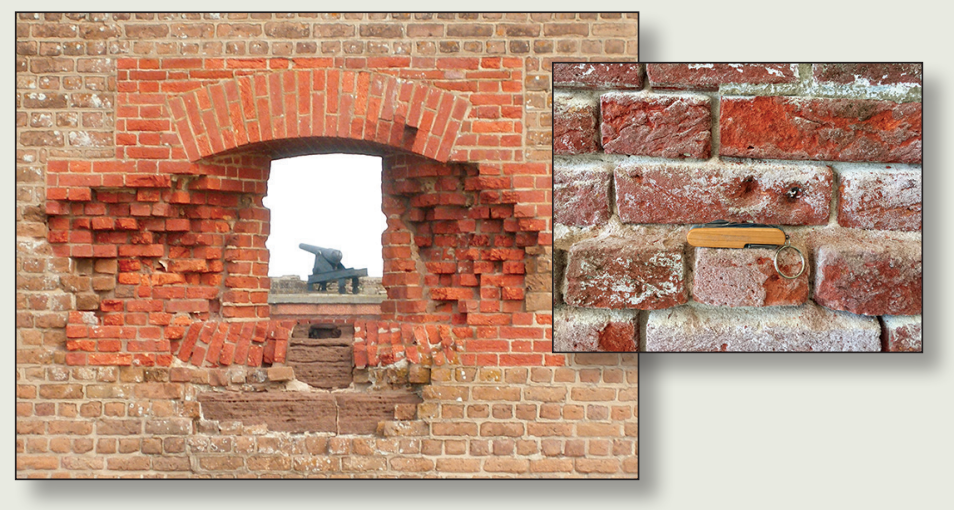

B. Bricks - The following two kinds of bricks were made for building stone using mud and sand:

1. "Rose-red" bricks were used in arches and interior walls. The mud and sand for these bricks were excavated from land near the fort.

2. "Rose-brown" bricks were used in the exterior walls and in the walls that line the moat. These bricks were made in Baltimore, Md., and Alexandria, Va. The mud was probably derived from extremely weathered metamorphic rocks.

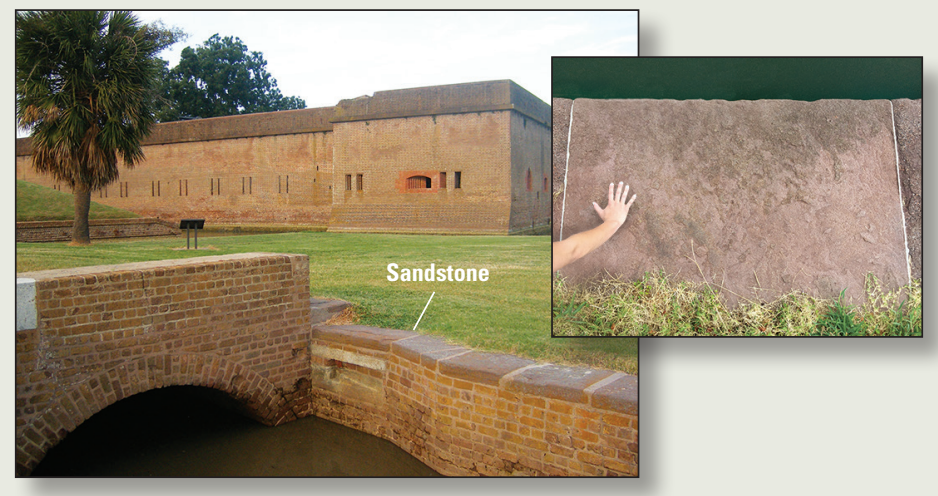

C. Sandstone-Blocks of brownish-red sandstone were used to border the moat and to line thresholds of interior doorways and brick arches. Sandstone is a sedimentary rock composed of sand-size particles eroded from other rocks. This sandstone was quarried in Connecticut from the Portland Formation of the Newark Supergroup, and then transported to Fort Pulaski. The quarried sandstone is informally called "Portland brownstone." This sandstone is approximately 190 to 200 million years old, and accumulated in basins on land when the Atlantic Ocean was opening during the splitting apart of the supercontinent Pangaea.

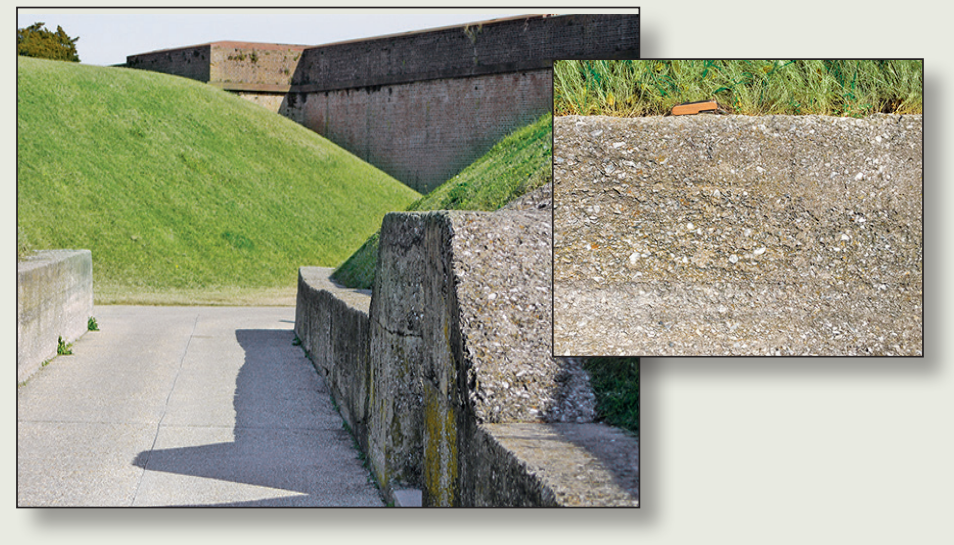

D. Lime mud with oyster shells - Cement composed of lime mud and oyster shells was used in the walkway through the demilune moat of Fort Pulaski. This cement (informally called "tabby") was used as mortar between bricks and as coating over bricks. The cement was made by crushing and burning the shells to make a powdered material called lime. The lime was then combined with water, sand, ash (from burned wood), and more crushed oyster shells, and was poured into wooden molds and left to harden. This method of making cement was used in the construction of many coastal forts during the $1800 \mathrm{~s}$. The oyster shells were probably obtained from Native American middens in the vicinity of the Savannah River.

Figure 4. $\boldsymbol{A}-\boldsymbol{D}$, Photographs of building stones of Fort Pulaski National Monument. Data are from Young (1936), Eldridge (1996), Weems and Olsen (1997), Ryan (2008), and LeTourneau (2010). A 3.5-inch (8.9-cm)-long pocketknife (in $\boldsymbol{A}, \boldsymbol{B}$, and $\boldsymbol{D}$ ) and a hand (in $\boldsymbol{C}$ ) are shown for scale. Smaller photographs in $\boldsymbol{A}-\boldsymbol{D}$ by Mercer Parker, U.S. Geological Survey. 

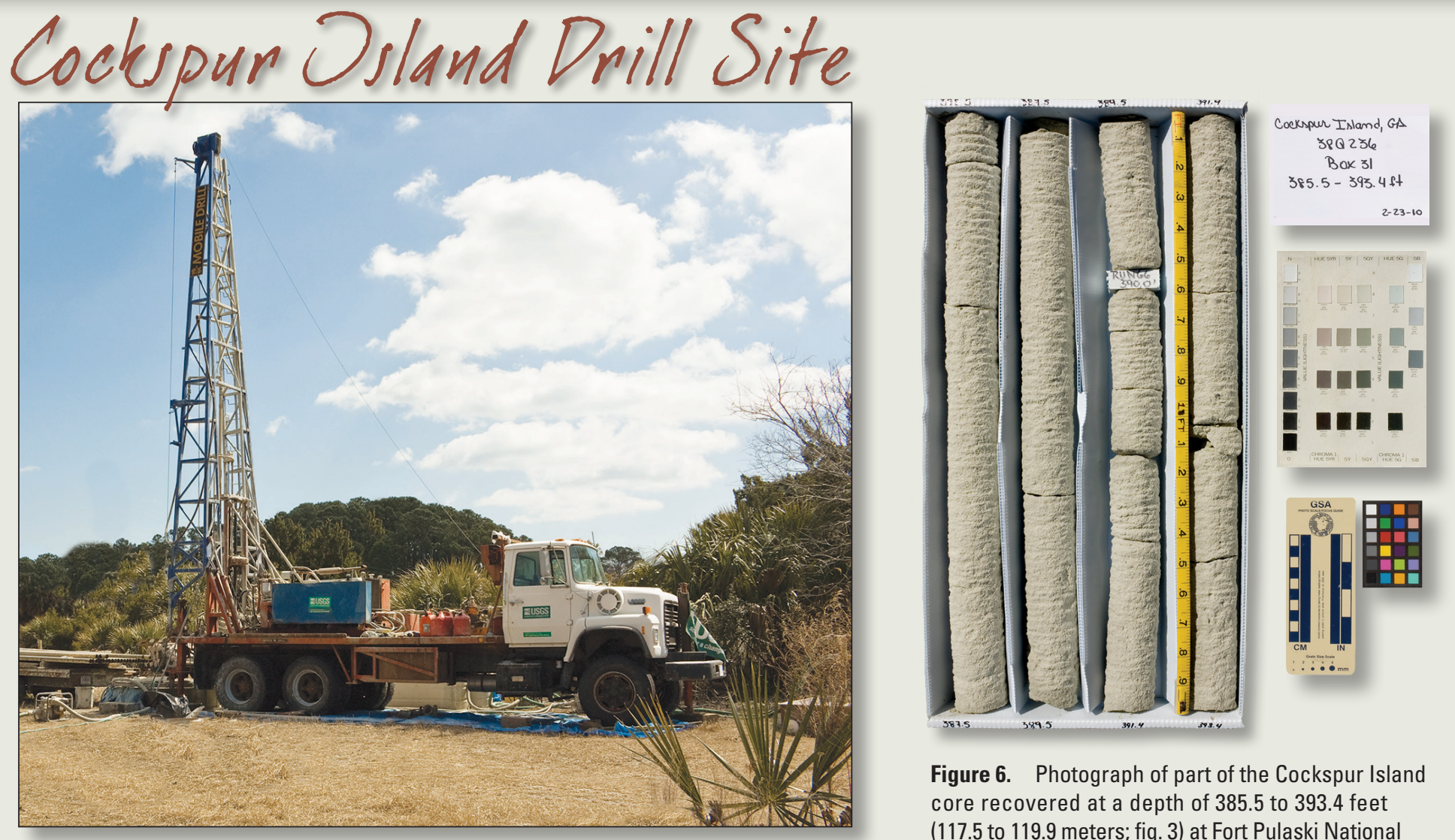

Figure 6. Photograph of part of the Cockspur Island core recovered at a depth of 385.5 to 393.4 feet (117.5 to 119.9 meters; fig. 3) at Fort Pulaski National Monument during February 2010; color charts and scales are also shown. Photograph by Wilma AlemánGonzález, U.S. Geological Survey.

Island drill site at Fort Pulaski National Monument during February 2010. Photograph by Colleen T. Durand (USGS).

\section{References Cited}

Alemán-González, W.B., Swezey, C.S., Self-Trail, J.M., Edwards, L.E., and McGeehin, J.P., 2016, Preliminary Cenozoic lithostratigraphy of the Cockspur Island core, Fort Pulaski National Monument, Chatham County, Georgia: Geological Society of America, Abstracts with Programs, v. 48, no. 3, accessed December 2017, at https://doi.org/10.1130/abs/ 2016SE-272508.

Eldridge, D.P., 1996, Brick versus Earth-The construction and destruction of seacoast Forts Pulaski and McAllister, Georgia: Jacksonville, Florida, University of North Florida, M.A. thesis, 96 p.

LeTourneau, P.M., 2010, The stone that shaped America in the 19th centuryThe geology and history of the Portland brownstone quarries, chap. 3 of LeTourneau, P.M., and Thomas, M.A., eds., Traprock, tracks and brownstone-The geology, paleontology, and history of world-class sites in the Connecticut Valley: Geological Society of Connecticut Field Trip Guidebook No. 1, p. 17-30. [Also available at https://www. geologicalsocietyct.org/uploads/3/0/5/5/30552753/gsc_guidebook1final.pdf.]
Ryan, M., 2008, Survey of Fort Pulaski research material at the National Archives and Carlisle Barracks: U.S. National Park Service report, Fort Pulaski National Monument, Chatham County, Georgia, 4 p.

Weems, R.E., and Edwards, L.E., 2001, Geology of Oligocene, Miocene, and younger deposits in the coastal area of Georgia: Georgia Geologic Survey Bulletin 131, 124 p. [Also available at https://www2.usgs.gov/ water/southatlantic/ga/publications/ggs/bull-131/.]

Weems, R.E., and Olsen, P.E., 1997, Synthesis and revision of groups within the Newark Supergroup, eastern North America: Geological Society of America Bulletin, v. 109, no. 2, p. 195-209. [Also available at https://pubs. geoscienceworld.org/gsa/gsabulletin/article/109/2/195-209/183209.]

Williams, L.J., and Kuniansky, E.L., 2016, Revised hydrogeologic framework of the Floridan aquifer system in Florida and parts of Georgia, Alabama, and South Carolina (ver. 1.1, March 1, 2016): U.S. Geological Survey Professional Paper 1807, 140 p., 23 pls., accessed December 2017, at https://pubs.usgs.gov/pp/1807/.

Young, R.W., 1936, The construction of Fort Pulaski: The Georgia Historical Quarterly, v. 20, no. 1, p. 41-51. [Also available at http://www.jstor.org/ stable/i40024843.]

\section{Contact Information}

Christopher S. Swezey U.S. Geological Survey 12201 Sunrise Valley Dr., MS 926A Reston, VA 20192 Telephone: 703-648-6444 E-mail: cswezey@usgs.gov
Ellen L. Seefelt

U.S. Geological Survey

12201 Sunrise Valley Dr., MS 926A

Reston, VA 20192

Telephone: 703-648-6006

E-mail: eseefelt@usgs.gov
Mercer Parker

U.S. Geological Survey

12201 Sunrise Valley Dr., MS 926A

Reston, VA 20192

Telephone: 703-648-6924

E-mail: mercerparker@usgs.gov
Image and Photograph Credits

Aerial view of Fort Pulaski-Edibobb, Creative Commons 3.0

Fort Pulaski Civil War drawing — Public Domain

Cannon above wall-Bubba73 at English Wikipedia, Creative Commons 3.0

Moat and bridge-Billy Hathorn, Creative Commons 3.0 Oyster shell wall-Marc Smith, Creative Commons 2.0, https://creativecommons.org/licenses/by/2.0/

USGS photograph attribution included in captions. All other photographs courtesy of the National Park Service. 